\title{
Transport and build-up of tropospheric trace gases during the MINOS campaign: comparision of GOME, in situ aircraft measurements and MATCH-MPIC-data
}

\author{
A. Ladstätter-Weißenmayer ${ }^{1}$, J. Heland ${ }^{2}$, R. Kormann ${ }^{3}$, R. von Kuhlmann ${ }^{3}$, M. G. Lawrence ${ }^{3}$, J. Meyer-Arnek ${ }^{1}$, \\ A. Richter ${ }^{1}$, F. Wittrock ${ }^{1}$, H. Ziereis ${ }^{3}$, and J. P. Burrows ${ }^{1}$ \\ ${ }^{1}$ Institute of Environmental Physics, University of Bremen, P.O. Box 330440, D-28334 Bremen, Germany \\ ${ }^{2}$ Institute of Atmospheric Physic, DLR, Oberpfaffenhofen, D-82234 Wessling, Germany \\ ${ }^{3}$ Max-Planck-Institute for Chemistry, P.O. Box 3060, D-55020 Mainz, Germany
}

Received: 4 March 2003 - Published in Atmos. Chem. Phys. Discuss.: 5 June 2003

Revised: 7 October 2003 - Accepted: 13 October 2003 - Published: 31 October 2003

\begin{abstract}
The MINOS (Mediterranean INtensive Oxidant Study) campaign was an international, multi-platform field campaign to measure long-range transport of air-pollution and aerosols from South East Asia and Europe towards the Mediterranean basin during August 2001. High pollution events were observed during this campaign. For the Mediterranean region enhanced tropospheric nitrogen dioxide $\left(\mathrm{NO}_{2}\right)$ and formaldehyde ( $\mathrm{HCHO})$, which are precursors of tropospheric ozone $\left(\mathrm{O}_{3}\right)$, were detected by the satellite based GOME (Global Ozone Monitoring Experiment) instrument and compared with airborne in situ measurements as well as with the output from the global 3D photochemistry-transport model MATCH-MPIC (Model of Atmospheric Transport and CHemistry - Max Planck Institute for Chemistry). The increase of pollution in that region leads to severe air quality degradation with regional and global implications.
\end{abstract}

\section{Introduction}

The rapid growth of human population and industrial development in South-East Asia and Europe is accompanied by an increase of air pollution. The consequence is increasing trace gas production and release into the atmosphere by human activities which are significantly disturbing the composition and chemistry of the global atmosphere and increasing the concentration of atmospheric greenhouse gases that control the climate of our planet (Levine, 1991). Combustion processes lead to emissions of trace gases like carbondioxide $\left(\mathrm{CO}_{2}\right)$, carbon monoxide $(\mathrm{CO})$, nitrogen oxides $\left(\mathrm{NO}_{\mathrm{x}}\right)$ $\left[\mathrm{NO}_{\mathrm{x}}=\mathrm{NO}+\mathrm{NO}_{2}\right]$, methane $\left(\mathrm{CH}_{4}\right)$, nonmethane hydrocar-

Correspondence to: A. Ladstätter-Weißenmayer (lad@iup.physik.uni-bremen.de) bons (NMHC) and especially formaldehyde (HCHO), which is also produced by photochemical reactions (LadstätterWeissenmayer et al., 1998). These reactive gases strongly influence the local and downwind concentrations of the major oxidant ozone $\left(\mathrm{O}_{3}\right)$.

In this paper, we evaluate measurements of the Mediterranean INtensive Oxidant Study (MINOS) 2001 campaign to characterize the atmospheric chemical composition of SEAsian and European outflow from July and August 2001 over the Mediterranean basin. This time period was selected because northeasterly winds are persistent during this period and convection over the continental source regions is suppressed by large-scale subsidence, thus limiting the upward dispersion of pollution. As part of this MINOS campaign the Department of Environmental Physics and Remote Sensing (IUP), University of Bremen, Germany, analysed satellite based GOME data to compare the results to in-situ aircraft profile measurements of $\mathrm{NO}_{2}$ (performed by the Institute of Atmospheric Physics, DLR (Deutsches Zentrum für Luft- und Raumfahrt), Oberpfaffenhofen) and of $\mathrm{HCHO}$ (provided by the Max Planck Institute for Chemistry, Mainz). While for $\mathrm{NO}_{2}$ a similar study based on on aircraft profile has already been presented by Heland et al. (2002), this is the first time that GOME HCHO measurements are also compared to airborne in-situ measurements. The same data are also compared to output from the MATCH-MPIC-model, operated by the Max Planck Institute for Chemistry, Mainz (Von Kuhlmann, 2001; Von Kuhlmann et al., 2003; Lawrence et al., 1999) as a further validation of this model.

In addition, the GOME $\mathrm{NO}_{2}$ and $\mathrm{HCHO}$ measurements are also used to investigate transport and build-up of tropospheric pollution over the Mediterranean basin on a regional scale using a trajectory model. 


\section{Experimental setup}

\subsection{GOME measurements}

The Global Ozone Monitoring Experiment GOME was launched in April 1995 onboard the European Research Satellite (ERS)-2 into a near-sun-synchronous orbit at a mean altitude of $795 \mathrm{~km}$. The descending mode crosses the equator every $2800 \mathrm{~km}$ at 10:30 am local time. GOME is a nadir-scanning double-monochromator measuring the sunlight scattered from Earth's atmosphere and/or reflected by the surface in the wavelength region of 240 to $790 \mathrm{~nm}$ at a moderate spectral resolution of 0.17 to $0.33 \mathrm{~nm}$. Once per day the extraterrestrial solar irradiance is measured and can be used as an absorption free background in the data analysis. The spectrum is subdivided into four spectral channels, each recorded quasi-simultaneously by a 1024-pixel reticon photodiode-array. With 14 orbits per day, total ground coverage is obtained within 3 days at the equator by a $960 \mathrm{~km}$ across-track swath ( $4.5 \mathrm{~s}$ forward scan, $1.5 \mathrm{~s}$ back scan, the size of one GOME ground pixel is $40 \times 320 \mathrm{~km}^{2}$ ). GOME measurements are available for the time period from July 1995 to June 2003. The main scientific objective of GOME is to measure the global distribution of $\mathrm{O}_{3}$ and several other trace gases which play an important role in the ozone chemistry of the Earth's stratosphere and troposphere, e.g. $\mathrm{NO}_{2}$, $\mathrm{BrO}, \mathrm{OClO}, \mathrm{SO}_{2}, \mathrm{H}_{2} \mathrm{O}$, and $\mathrm{HCHO}$. Details of the overall scientific results are reported elsewhere (Burrows et al., 1999, 2000). In addition, a number of studies has been published focusing on the retrieval of $\mathrm{NO}_{2}$ (Leue et al., 2001; Richter and Burrows, 2002; Martin et al., 2002) and HCHO (Ladstätter-Weissenmayer et al., 1998; Chance et al., 2000; Palmer et al., 2002) from GOME data.

During the summer in the boundary layer (BL) over the Mediterranean region the mixing ratios for $\mathrm{NO}_{2}$ are usually in a range of $0.2-0.7 \mathrm{ppb}$ (measured by M. Vrekoussis with a long-path DOAS (Differential Optical Absorption Spectroscopy)-system during the MINOS campaign) near the surface. For HCHO a mixing ratio of $200 \pm 70 \mathrm{ppt}$ was measured during the INDOEX-campaign (Wagner et al., 2002) in the marine boundary layer over the Indian Ocean, whereas an average value of $1.6 \mathrm{ppb}$ was observed during the MINOS campaign (Kormann et al., 2003). GOME is able to measure both trace gases with a detection limit of $5 \cdot 10^{14} \mathrm{molec} / \mathrm{cm}^{2}(\sim 100 \mathrm{ppt}$, assuming a $2 \mathrm{~km}$ thick atmospheric layer at $1000 \mathrm{hPa}$ ) for $\mathrm{NO}_{2}$ and $2.5 \cdot 10^{15} \mathrm{molec} / \mathrm{cm}^{2}$ ( $\sim 500 \mathrm{ppt}$, assuming a $2 \mathrm{~km}$ atmospheric layer at $1000 \mathrm{hPa})$ for $\mathrm{HCHO}$.

Since GOME is measuring the sunlight backscattered from the earth surface, the presence of clouds influences the results of the data analysis. For this study only GOME measurements under clear sky conditions were used for the comparisons with in-situ measurements and modeled MATCHMPIC results (Lawrence et al., 2003). Here we define cloud free as a cloud-cover of less than $10 \%$ as determined with the operational GOME ICFA algorithm (see Figs. 1a and $b$ where white gaps reflect pixels with cloud cover higher than $10 \%$ or errors above a threshold value; for $\mathrm{NO}_{2}$ of $50 \%$ and for $\mathrm{HCHO}$ of $100 \%)$.

The number of overflights of GOME over this region during the MINOS campaign and the restriction to cloud-free scenes are the limiting factor for the number of comparisons.

\subsection{Airborne in situ measurements}

In-situ measurements of nitrogen monoxide (NO), $\mathrm{O}_{3}$, $\mathrm{HCHO}$, the photolysis frequency of $\mathrm{NO}_{2}\left(\mathrm{~J}\left(\mathrm{NO}_{2}\right)\right)$ and meteorological parameters were performed with the Falcon research aircraft of DLR. NO was measured by means of a well characterized chemiluminescence detector (CLD) with a detection limit of about $5 \mathrm{pptV}$ for NO. The nominal accuracy of the measurements during the MINOS campaign was $5 \%$ of the measured value (Ziereis et al., 1999). Before every flight a calibration of this instrument was performed using a diluted mixture of $2.97 \mathrm{ppmV} \mathrm{NO} \pm 1 \%$ in $\mathrm{N}_{2}$ (Messer Griesheim) with purified air.

$\mathrm{O}_{3}$ was measured by UV-absorption with a modified TE 49 instrument (Thermo Environmental) calibrated with an $\mathrm{O}_{3}$ $41 \mathrm{M}$ ozone generator (ANSYCO) which is frequently calibrated against a GAW (Global Atmosphere Watch) standard device. The accuracy of the ozone measurements is estimated to be within $5 \%$.

The photolysis frequency of $\mathrm{NO}_{2}$ was obtained from the sum of two filter radiometers (Meteo Consult $\mathrm{GmbH}$ ) (Junkermann et al., 1989; Volz-Thomas, 1996) with $2 \pi$ viewing geometry and an overall uncertainty of $17 \%$. One of the radiometers was installed on top of the aircraft, the second on the downward facing side of the aircraft body. The detectors were optimized for flight applications (Volz-Thomas, 1996) and have recently been characterized in the laboratory (Hauser, 2002).

HCHO measurements during MINOS were based on the Hantzsch reaction technique (Nash, 1953) and carried out with an Aero Laser (AL4021, Aero Laser GmbH, GarmischPartenkirchen, Germany) modified for airborne operation. The detection limit of the instrument was $42 \mathrm{pptv}$ at a time resolution of $180 \mathrm{~s}(10-90 \%)$. The total uncertainty of $\mathrm{HCHO}$ for the measurements during the MINOS campaign is estimated to be $30 \%$ at a mixing ratio of 300 pptv (Kormann et al., 2003). Similar measurement techniques are described elsewhere in the literature (Kelly and Fortune, 1994; Macdonald et al., 1999).

\subsection{MATCH-MPIC-model}

The MATCH-MPIC model (Lawrence et al., 1999) has been developed and applied towards the investigation of global tropospheric chemistry. It is an "offline" model which can be driven with gridded time-dependent values from different meteorological datasets. Here, the National Center 

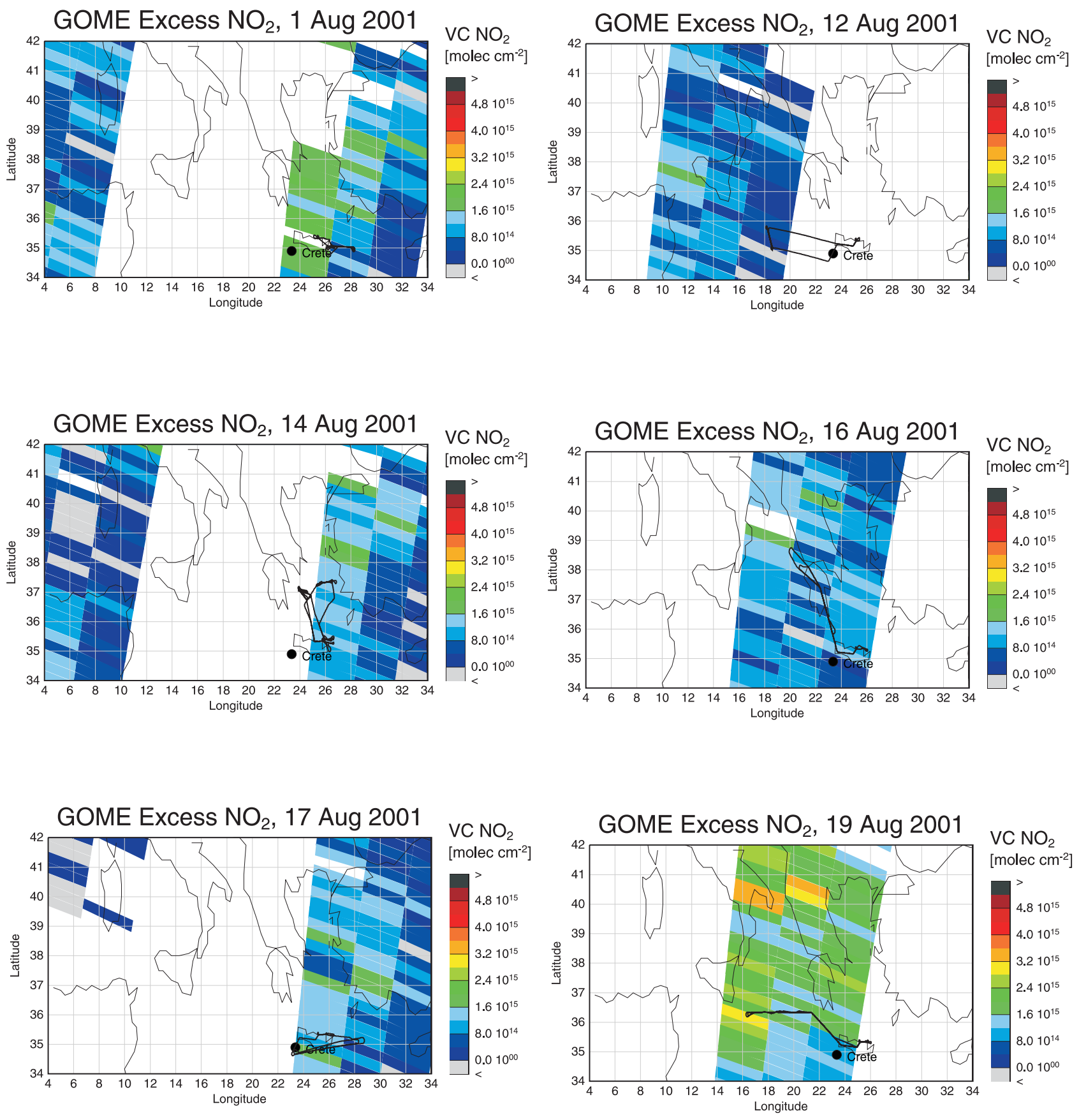

Fig. 1a. Vertical tropospheric columns of $\mathrm{NO}_{2}$ derived from GOME measurements and Falcon flight tracks on the days of overflights of GOME during the MINOS campaign.

for Environmental Prediction (NCEP), GFS (Global Forecast/Analysis System), - formerly known as "AVN" - data at a horizontal resolution of about $2.8^{\circ} \times 2.8^{\circ}$ with 42 levels are used for the period of the MINOS campaign (Lawrence et al., 2003). Emissions of 16 species from industrial activities (based on the EDGAR database, Olivier et al. (1996)), biomass burning, the terrestrial biosphere itself and the ocean were taken into account. The chemical scheme of the model includes $\mathrm{CH}_{4}-\mathrm{CO}-\mathrm{HO}_{\mathrm{x}}-\mathrm{NO}_{\mathrm{x}}$ "background" chemistry, as well as representations of isoprene, ethane $\left(\mathrm{C}_{2} \mathrm{H}_{6}\right)$, propane $\left(\mathrm{C}_{3} \mathrm{H}_{8}\right)$, ethylene $\left(\mathrm{C}_{2} \mathrm{H}_{4}\right)$, propylene $\left(\mathrm{C}_{3} \mathrm{H}_{6}\right)$ and higher alkanes. A complete description of the model can be found in Lawrence et al. (1999); Von Kuhlmann (2001); Von Kuhlmann et al. (2003). 

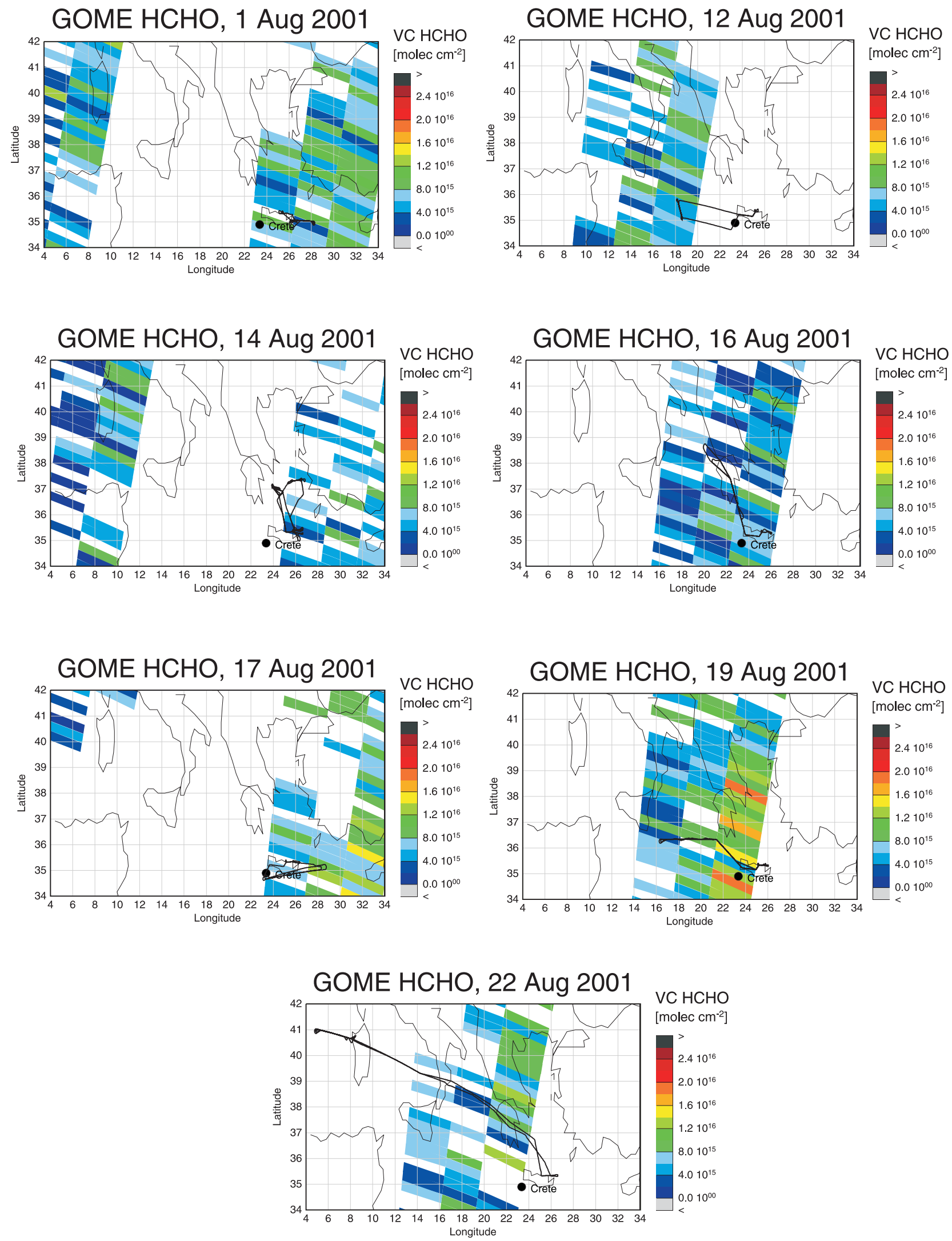

Fig. 1b. Vertical tropospheric columns of HCHO derived from GOME measurements and Falcon flight tracks on the days of overflights of GOME during the MINOS campaign. 


\section{Data analysis}

\subsection{GOME data analysis}

For the comparisons with the airborne in-situ measurements, GOME data, more precisely those pixels along the flight track of the Falcon, were extracted and analysed (see Figs. 1a and $b$ ) for the trace gases $\mathrm{HCHO}$ and $\mathrm{NO}_{2}$. GOME spectra were analysed using the IUP Bremen Differential Optical Absorption (DOAS) algorithm (Burrows et al., 1999; Richter and Burrows, 2002) to derive slant columns of $\mathrm{HCHO}$ and $\mathrm{NO}_{2}$. Slant columns are the total amount of the absorber integrated along all contributing light paths through the atmosphere. To convert this quantity into vertical columns which are independent of the viewing geometry, airmass factors (AMFs) were computed with the radiative transfer model GOMETRAN (Rozanov et al., 1997). The AMF are the ratio between slant column and vertical column determined for a model atmosphere and depend critically on assumptions made for surface albedo, aerosol loading and the vertical distribution of the absorber of interest. Details on the spectral analysis are given elsewhere (Ladstätter-Weissenmayer et al., 1998; Richter and Burrows, 2002) and are not repeated here.

As GOME is a nadir viewing instrument, both tropospheric and stratospheric absorptions contribute to the measured signal. While this is not critical for $\mathrm{HCHO}$ which has a very small stratospheric column, the stratospheric $\mathrm{NO}_{2}$ column can not be neglected in the analysis. Therefore, the Tropospheric Excess Method (TEM) (Fishman et al., 1990; Leue et al., 2001; Richter and Burrows, 2002) was used to derive the tropospheric columns of $\mathrm{NO}_{2}$. This method is based on the assumption that stratospheric $\mathrm{NO}_{2}$ does not vary zonally, and therefore the total columns measured on the same day at the same latitude over a clean air region can be used as an approximation of the stratospheric column over the region of interest. Here, data from Atlantic region $\left(315-325^{\circ}\right)$, which at these latitudes can be considered to be relatively clean, were used as the clean atmospheric background. The overall analysis then consists of three steps: (a) determination of the total slant column, (b) subtraction of the stratospheric contribution yielding the tropospheric slant column and (c) division by the airmass factor to obtain the vertical tropospheric column.

The TEM works under the assumption that the variations in the $\mathrm{NO}_{2}$ vertical columns detected by GOME can be attributed to variations in tropospheric $\mathrm{NO}_{2}$ columns. There are general limitations using this method which introduce some uncertainty into the results. Also, a number of assumptions has to be made for the calculation of the airmass factors, and they also contribute to the overall error of the GOME measurements. A detailed discussion of the error budget is given in Richter and Burrows (2002). The main error sources are the inhomogeneities in the stratospheric $\mathrm{NO}_{2}$ field, uncertainties in cloud cover, the assumed vertical profile of $\mathrm{NO}_{2}$, the surface albedo and the aerosol loading which are required

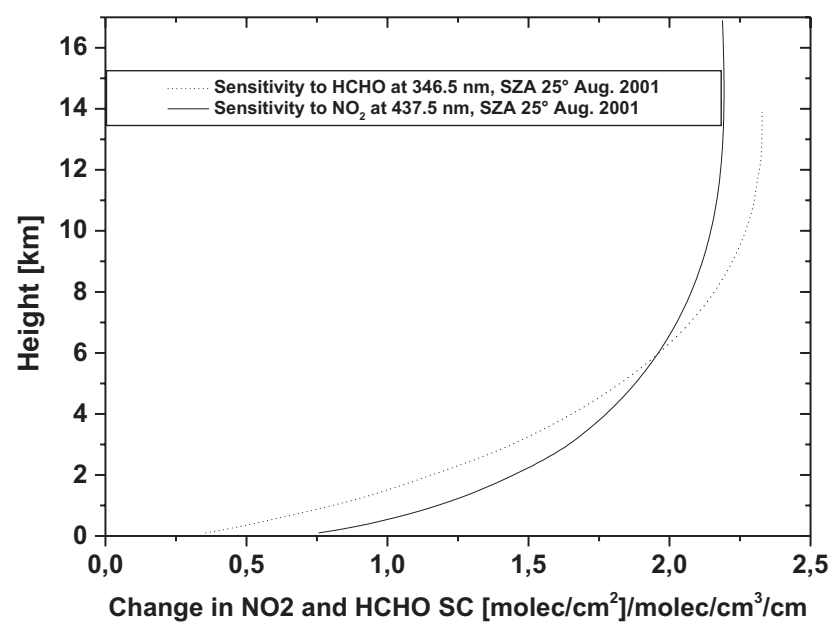

Fig. 2. Weighting function for $\mathrm{NO}_{2}$ at $437.5 \mathrm{~nm}, 25^{\circ} \mathrm{SZA}$. Shown is the sensitivity of the measured slant column to a change in $\mathrm{NO}_{2}$ and $\mathrm{HCHO}$ concentration at a given height. For an optically thin atmosphere, the figure is identical to a vertical AMF distribution (block airmass factor). The weighting function has no units as it gives the change in slant column (units $\mathrm{molec} / \mathrm{cm}^{2}$ ) for a change in concentration (units molec/ $\mathrm{cm}^{3}$ ) in a layer of $1 \mathrm{~cm}$ thickness.

in calculating the AMF. The overall error of the analysis is estimated to be on the order of $1.5 \times 10^{15} \mathrm{molec} / \mathrm{cm}^{2}$ (see Table 1). For HCHO, the stratosphere is no concern, but fitting errors are larger and in contrast to $\mathrm{NO}_{2}$ contribute significantly to the overall error.

One major concern in the analysis of tropospheric columns derived from spaceborne UV/visible measurements is the question of how sensitive the measurement is to contributions from different altitudes. This can be evaluated using the well known concept of weighting functions, which are a measure of the change in measured quantity (here the slant columns) for a change of the target quantity (here the concentration of $\mathrm{NO}_{2}$ or $\mathrm{HCHO}$ ) as a function of altitude. It should be noted, that for an optically thin atmosphere, the weighting functions are identical to block airmass factors which give the AMF for thin layers of absorbers at different altitudes (see also the discussion of Eskes and Boersma (2003)). Weighting functions were calculated for both $\mathrm{NO}_{2}$ and $\mathrm{HCHO}$ for a typical scenario during the MINOS campaign $\left(\mathrm{SZA}=25^{\circ}\right.$ ) using the radiative transport model GOMETRAN. The results are shown in Fig. 2. The two curves differ as HCHO is retrieved at shorter wavelengths and therefore Rayleigh scattering is more important. As can be seen from the plot, the sensitivity of the satellite measurements decreases towards the surface, in particular for HCHO. This has to be accounted for in the analysis by use of an adequate vertical profile in the AMF calculation, and potentially can introduce large errors in the satellite data.

In this study, for the comparison with in-situ measurements, various AMF based on different vertical profiles 
Table 1. Contribution of possible error sources in the GOME analysis to the uncertainty of the retrieved tropospheric columns of $\mathrm{NO}_{2}$ and $\mathrm{HCHO}$

\begin{tabular}{lll}
\hline Error source & Uncertainty $\left(\mathrm{NO}_{2}\right)$ & Uncertainty $(\mathrm{HCHO})$ \\
\hline Fitting error & $5 \%$ & $50 \%$ \\
Stratospheric subtraction & $0.5 \times 10^{15} \mathrm{molec} / \mathrm{cm}^{2}$ & - \\
$\mathrm{NO}_{2}-\mathrm{HCHO}$ vertical profile assumption (AMF) & $50 \%$ & $50 \%$ \\
Aerosol assumption (AMF) & $35 \%$ & $35 \%$ \\
Surface albedo assumption (AMF) & $\max .50 \%$ & max. $50 \%$ \\
Cloud effects & $30 \%$ & $30 \%$ \\
Overall error of the analysis & $1.5 \times 10^{15} \mathrm{molec} / \mathrm{cm}^{2}$ & - \\
\hline
\end{tabular}

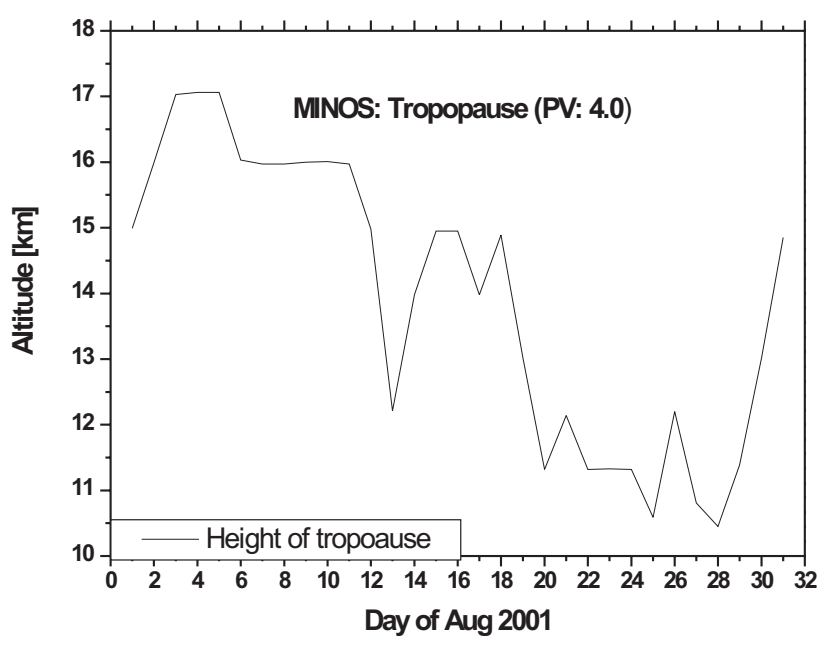

Fig. 3. Tropopause height (defined to be at the altitude of 4 PVUnits) over Crete during the MINOS campaign in August 2001.

(the individual and the averaged profiles) were used for the GOME analyses to determine the tropospheric vertical columns. This is discussed in detail in Sect. 4.1.

For the comparison between GOME, in-situ measurements, and model data, the latter have to be converted to vertical columns, usually by integrating all values from the surface up to the tropopause. Unfortunately, the Mediterranean region exhibits a large variability in tropopause height (Shimizu and Tsuda, 2000) which needs to be taken into account. In the vertical profiles of $\mathrm{O}_{3}$ measured by the in-situ instruments up to a height of $13 \mathrm{~km}$, an increase of the concentration was observed at $12 \mathrm{~km}$ height most likely originating from an influence of stratospheric air masses at this altitude e.g. on 22 August 2001. In order to determine tropopause heights above the highest flight level, the height of the tropopause was defined to be at the altitude of 4 PV-Units for the MINOS campaign (see Fig. 3). Using the ECMWF-operational analysis data at a $1.5 \times 1.5^{\circ}$ resolution based on 60 layers of the analysis-model, tropopause heights were determined based on the above definition and used throughout the analysis. Fortunately, variations in tropopause height in this altitude range have almost no influence on the tropospheric vertical columns of $\mathrm{NO}_{2}$ and $\mathrm{HCHO}$ which is in contrast to the situation for $\mathrm{O}_{3}$. The reason for this behaviour is the vertical profile of these trace gases which usually shows small values around the tropopause region.

\subsection{In-situ airborne data analysis}

\subsection{1 $\quad \mathrm{NO}_{2}$}

The profiles of the airborne measurements like $\mathrm{NO}, \mathrm{O}_{3}$, $\mathrm{HCHO}$ and in addition $\mathrm{J}\left(\mathrm{NO}_{2}\right)$ were analysed in combination with meteorological data. To obtain the $\mathrm{NO}_{2}$ concentrations, we assumed a simple photochemical equilibrium between $\mathrm{NO}, \mathrm{NO}_{2} \mathrm{O}_{3}$ and $\mathrm{J}\left(\mathrm{NO}_{2}\right)$ (e.g. Atkinson (2000)), where the temperature-dependent rate constant $k\left(\mathrm{NO}+\mathrm{O}_{3}\right)$ is calculated from the data given in Sander et al. (2000). For the purpose of data reduction, the airborne $\mathrm{NO}_{2}$ and $\mathrm{O}_{3}$ data ( $1 \mathrm{~Hz}$ values) were averaged in $100 \mathrm{~m}$ altitude bins for each profile as well as for an averaged $\mathrm{NO}_{2}$-profile. The error bars were evaluated from the spread of the experimental data in the bins $(1 \sigma)$ and the uncertainties for the $\mathrm{NO}_{2}$ and $\mathrm{O}_{3}$ data, respectively. One of the uncertainties for $\mathrm{NO}_{2}$ is the use of simple photochemical equilibrium between $\mathrm{NO}, \mathrm{NO}_{2} \mathrm{O}_{3}$ and $\mathrm{J}\left(\mathrm{NO}_{2}\right)$ and the assumption that $\mathrm{O}_{3}$ dominates the conversion of $\mathrm{NO}$ to $\mathrm{NO}_{2}$ (Calvert and Stockwell, 1983). In polluted regions, reactions involving peroxy radicals may also constitute potentially important conversion channels of NO to $\mathrm{NO}_{2}$ (Crawford et al., 1996). In addition, the temperaturedependent rate constant $k\left(\mathrm{NO}+\mathrm{O}_{3}\right)$, which is a function of non-linear pressure and temperature, can be considered as an uncertainty in the calculation of $\mathrm{NO}_{2}$. In case of missing data in intermediate altitude bins, a mean mixing ratio was defined within these bins and conservative assumptions about the uncertainties were made.

Since the in-situ data were collected up to altitudes of about $10-13 \mathrm{~km}$, the analysis of tropospheric vertical columns of $\mathrm{NO}_{2}$ can be carried out up to the height of $12 \mathrm{~km}$ (strong increase of $\mathrm{O}_{3}$ ) directly. However, the position of the 
height of the tropopause (which according to ECMWF data was in the range of 12.0 to $17.0 \mathrm{~km}$ altitude during the MINOS campaign; see Fig. 3) was above the top flight altitude on many days, and therefore data had to be extrapolated. A linear extrapolation of the $\mathrm{NO}_{2}$ mixing ratios was used starting from the value at the highest aircraft altitude and ending at the tropopause, with the highest value of $\mathrm{NO}_{2}$ measured in the free troposphere. The error bars for the extrapolated $\mathrm{NO}_{2}$ mixing ratios were set to be $\pm 100 \%$.

In order to obtain tropospheric columns of $\mathrm{NO}_{2}$, the number densities of this trace gas in the defined altitude bins were summed up and multiplied with the thickness of the bins, (i.e. $100 \mathrm{~m}$ ) and finally converted to molec $/ \mathrm{cm}^{3}$, taking into account the nonlinearity of pressure and temperature. The column uncertainties were calculated using the differences of the minimum or maximum values of the columns - as derived from the error bars - and the mean columns. The overall uncertainty of the nitrogen dioxide mixing ratios depends on the experimental uncertainties of the other gases, $\mathrm{J}\left(\mathrm{NO}_{2}\right)$, the reaction constant $k$, and on the unknown amount of $\mathrm{NO}_{2}$ produced by molecules other than $\mathrm{O}_{3}$ (e.g. $\mathrm{RO}_{2}$ ), and is estimated to be $\sim 25 \%$.

\subsection{2 $\mathrm{HCHO}$}

A detailed description of the $\mathrm{HCHO}$ data sampling procedure during the MINOS campaign and a discussion of the data quality is given in Kormann et al. (2003). Data in the lower and middle troposphere (heights of $600 \mathrm{~m}$ up to $13 \mathrm{~km}$ ) were obtained during some profile measurements. These profile measurements contained rapid ascents and descents of the Falcon as well as flights at a constant altitude. For the comparison with satellite based data and the model, calculated profiles from individual flights with a height resolution of $1 \mathrm{~km}$ as well as an averaged profile for the campaign were used. Before averaging the data of the HCHO-profiles in bins of $1 \mathrm{~km}$ the mixing ratios of $\mathrm{HCHO}$ were calculated in molec $/ \mathrm{cm}^{3}$ accounting for the non-linearity of pressure and temperature.

\subsection{MATCH-MPIC-model-data analysis}

The output of the MATCH-MPIC-model is based on data which are interpolated in space and time along the Falcon track (Lawrence et al., 2003). This was done rather than profiles only over Crete, so that the corresponding meteorological conditions for given temporal and spatial domains were used. The profiles of $\mathrm{NO}_{\mathrm{x}}, \mathrm{NO}, \mathrm{O}_{3}, \mathrm{HCHO}$ and in addition $\mathrm{J}\left(\mathrm{NO}_{2}\right)$ based on MATCH-MPIC-model-output were analysed. To obtain the $\mathrm{NO}_{2}$ concentrations and eventually the tropospheric vertical columns, the same photochemical equilibrium as described above, as well as the $\mathrm{NO}_{2}$ calculated from the difference between $\mathrm{NO}_{\mathrm{x}}$ and $\mathrm{NO}$ were used, whereas the $\mathrm{HCHO}$ mixing ratios could directly be retrieved from the MATCH-MPIC output. In order to reduce the size

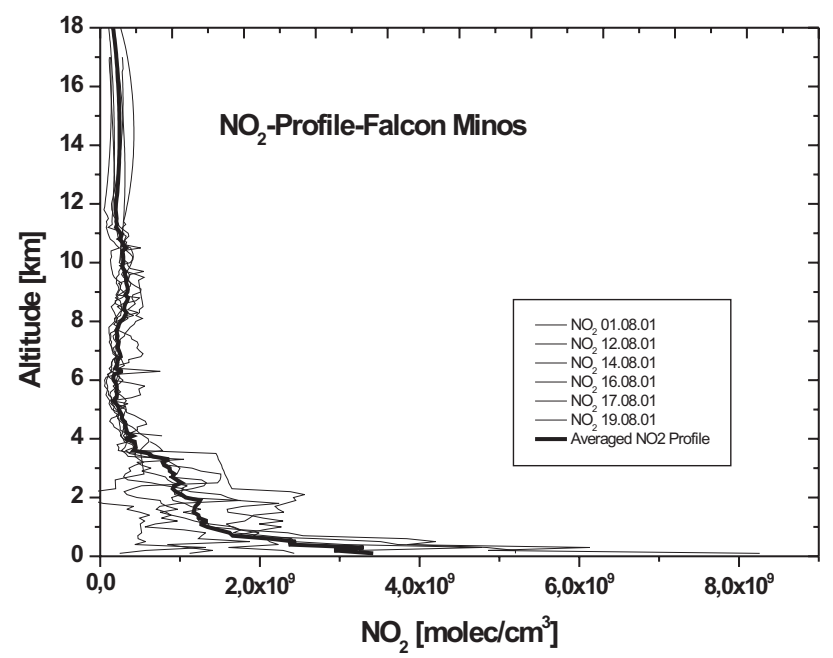

Fig. 4. Vertical profiles of $\mathrm{NO}_{2}$ and the calculated averaged profile based on in situ-measurements performed from the DLR-Falcon during the MINOS campaign in July and August 2001.

of the dataset for $\mathrm{NO}_{2}$, the values were averaged in $100 \mathrm{~m}$ and the output of $\mathrm{HCHO}$ in $1 \mathrm{~km}$ altitude bins, to be consistent with the in-situ measurements.

\section{Results and discussion}

As described above, the objectives of this study were to calculate the tropospheric amount of the satellite based GOME measurements for $\mathrm{NO}_{2}$ and $\mathrm{HCHO}$ and to compare these results with in-situ aircraft measurements as well as with the output of MATCH-MPIC during the MINOS campaign. The second aim was to interpret these data with the results of the regional GOME data with respect to transport and formation of tropospheric constituents during this campaign.

\subsection{Comparison of GOME, in-situ aircraft measurements and MATCH-MPIC-data over the Mediterranean re- gion}

Figure 4 shows the measured values of $\mathrm{NO}_{2}$-concentrations $\left(\right.$ molec $\left./ \mathrm{cm}^{3}\right)$ and the calculated averaged profile including the extrapolation of these data up to a height of $18 \mathrm{~km}$ with an error of $\pm 100 \%$. For HCHO no extrapolation for the measured and the calculated mean value was carried out and the results up to the maximum flight altitude of about $13 \mathrm{~km}$ are shown (see Fig. 5).

Due to the limited temporal and spatial overlap of GOME and aircraft data (e. g. on the 22nd of August 2001 when $\mathrm{HCHO}$ data are available but no $\mathrm{NO}_{2}$ measurements were performed), only the data of 6 days for $\mathrm{NO}_{2}$ (one flight on the 1st, 12th, 16th, 17th and two flights per day on the 14th and 19th of August 2001) and 7 days (one flight on the 1st, 12th, 16th, 17th, 19th and two flights per day on the 14th and 22nd 


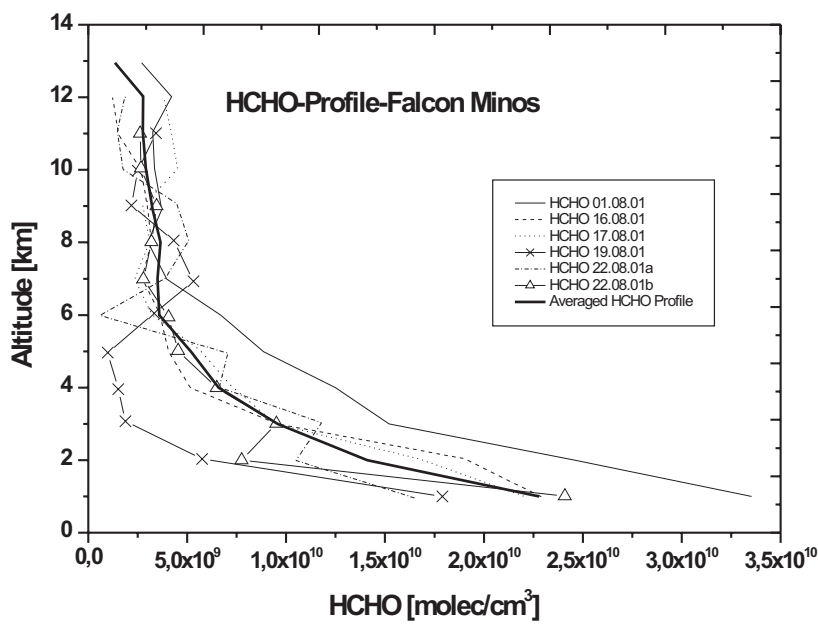

Fig. 5. Vertical profiles of $\mathrm{HCHO}$ and the calculated averaged profile based on in situ-measurements performed from the DLR-Falcon during the MINOS campaign in July and August 2001.

Table 2. Impact of using individual or averaged profiles for the calculation of the AMF on the tropospheric columns of $\mathrm{NO}_{2}$ and $\mathrm{HCHO}$.

\begin{tabular}{lll}
\hline & $\begin{array}{l}\text { Mean value of } \mathrm{NO}_{2} \\
{\left[\mathrm{molec} / \mathrm{cm}^{2}\right]}\end{array}$ & $\begin{array}{l}\text { Mean value of } \mathrm{HCHO} \\
{\left[\mathrm{molec} / \mathrm{cm}^{2}\right]}\end{array}$ \\
\hline $\begin{array}{l}\text { Individual profiles } \\
\begin{array}{l}\text { Averaged profile } \\
\text { for the campaign }\end{array}\end{array}$ & $\begin{array}{l}1.2 \times 10^{15} \\
8.7 \times 10^{14}\end{array}$ & $6.3 \times 10^{15}$ \\
& & $6.4 \times 10^{15}$ \\
\hline
\end{tabular}

of August 2001) for HCHO during the MINOS campaign could be analysed and compared (see Figs. 6 and 7).

For the GOME data, two different AMFs were calculated to determine the vertical columns from the slant columns of the GOME-data: (a) one set using all individual in-situ measured profiles for $\mathrm{NO}_{2}$ and $\mathrm{HCHO}$ and (b) another set using the averaged profile for the campaign for both trace gases.

The results for $\mathrm{NO}_{2}$ are shown in Fig. 6. The two different sets of AMFs result in differences of up to $25 \%$ $\left(2.6 \times 10^{14} \mathrm{molec} / \mathrm{cm}^{2}\right)$ in the tropospheric vertical column of $\mathrm{NO}_{2}$, demonstrating the impact of profile variability on the retrieval of the satellite data. While this uncertainty can not be neglected, it still is smaller than the overall uncertainties of the GOME retrievals of tropospheric $\mathrm{NO}_{2}$ $\left(4.5 \times 10^{14} \mathrm{molec} / \mathrm{cm}^{2}\right)$ (see Table 2$)$.

A similar comparison using different AMFs as described for $\mathrm{NO}_{2}$ was also carried out for the retrieval of the tropospheric vertical columns of HCHO (see Fig. 7). However, in contrast to $\mathrm{NO}_{2}$, the impact of $\mathrm{HCHO}$ profile changes during the campaign was small (difference of $1.3 \times 10^{13} \mathrm{molec} / \mathrm{cm}^{2}$; $\sim 0.5 \%$ ) (see Table 2).

For the intercomparison of GOME and in-situmeasurements as well as MATCH-MPIC-model outputs,
$\mathrm{NO}_{2}$ values averaged over $100 \mathrm{~m}$ bins were compared. Within the combined uncertainties, the GOME and in-situ measurements agree with each other and with the calculated model results during the whole campaign period. Taking into account the error bars of both, the aircraft and the satellite based data, the two instruments also agree within their accuracy limits in most cases (see Fig. 6). This means that the discrepancy between GOME and the in-situ-data is in the range of the standard deviation of the in-situ-measurements and the model.

When the mean campaign values of $\mathrm{NO}_{2}$ from GOME (using the individual profiles) and in-situ measurements are compared, the difference is $3.6 \times 10^{14} \mathrm{molec} / \mathrm{cm}^{2}$ when assuming a tropopause height of $17 \mathrm{~km}$ and $4.6 \times 10^{14} \mathrm{molec} / \mathrm{cm}^{2}$ for a tropopause height of $12 \mathrm{~km}$.

The comparison between GOME and MATCH-MPIC shows a difference of $2.7 \times 10^{14} \mathrm{molec} / \mathrm{cm}^{2}$ for the simple photochemical equilibrium between $\mathrm{NO}, \mathrm{NO}_{2} \mathrm{O}_{3}$ and $\mathrm{JNO}_{2}$. When using the $\mathrm{NO}_{2}$ derived from the difference between $\mathrm{NO}_{\mathrm{x}}$ and $\mathrm{NO}$ for a tropopause height of $12 \mathrm{~km}$ a deviation of $1.9 \times 10^{14} \mathrm{molec} / \mathrm{cm}^{2}$ is obtained. The main difference between the two approaches is, that the additional conversion of $\mathrm{NO}$ to $\mathrm{NO}_{2}$ by peroxy radicals was taken into account in the MATCH-MPIC-simulation to calculate the output of $\mathrm{NO}_{\mathrm{x}}$. Thus, accounting for the influence of hydrocarbons in photochemical reactions to produce $\mathrm{NO}_{2}$ reduces the difference between GOME and the output of model data to $30 \%$.

The average $\mathrm{NO}_{2}$-profile (see Fig. 4), taking into account the vertical distribution between $0-17 \mathrm{~km}$ altitude reflects that the main part of the tropospheric amount $\left(7.1 \times 10^{14}\right.$ molec $/ \mathrm{cm}^{2}$ ) is observed in the BL. The partition of the vertical $\mathrm{NO}_{2}$-profile in the different atmospheric layers $0-1 \mathrm{~km}$, $1-2 \mathrm{~km}, 2-3 \mathrm{~km}, 3-4 \mathrm{~km}$ reflects that $68 \%$ of tropospheric $\mathrm{NO}_{2}$ were observed in the lowest atmospheric layer, $11.5 \%$ in an altitude between $1-2 \mathrm{~km}, 5.6 \%$ between $2-3 \mathrm{~km}$ and $3.3 \%$ at a height of $3-4 \mathrm{~km}$ of the total column. Thus the rest of $11.6 \%$ of the tropospheric vertical column amount was detected above $4 \mathrm{~km}$. The good agreement between GOME and in-situ measurements for this situation demonstrates, that the satellite retrieval is able to provide accurate information even for situations where most of the $\mathrm{NO}_{2}$ is situated in the lowest atmospheric layers if this is accounted for in the AMF calculations.

In Fig. 7 the comparison of measured and modeled data is shown for the trace gas HCHO. For this case study the in-situ as well as the MATCH-MPIC-data were averaged in $1 \mathrm{~km}$ bins. For the first time a comparison between satellite based GOME and in-situ airborne measurements was carried out for the trace gas HCHO. During the MINOS campaign the results of both measurement systems agree well for the tropospheric vertical columns of HCHO. The difference between GOME and in-situ measurements is between $1.2 \times 10^{15} \mathrm{molec} / \mathrm{cm}^{2}$ and $5.6 \times 10^{15} \mathrm{molec} / \mathrm{cm}^{2}(<25 \%)$ for all comparisons when using the individual $\mathrm{HCHO}$-profiles for the AMF calculation. The discrepancy between the 


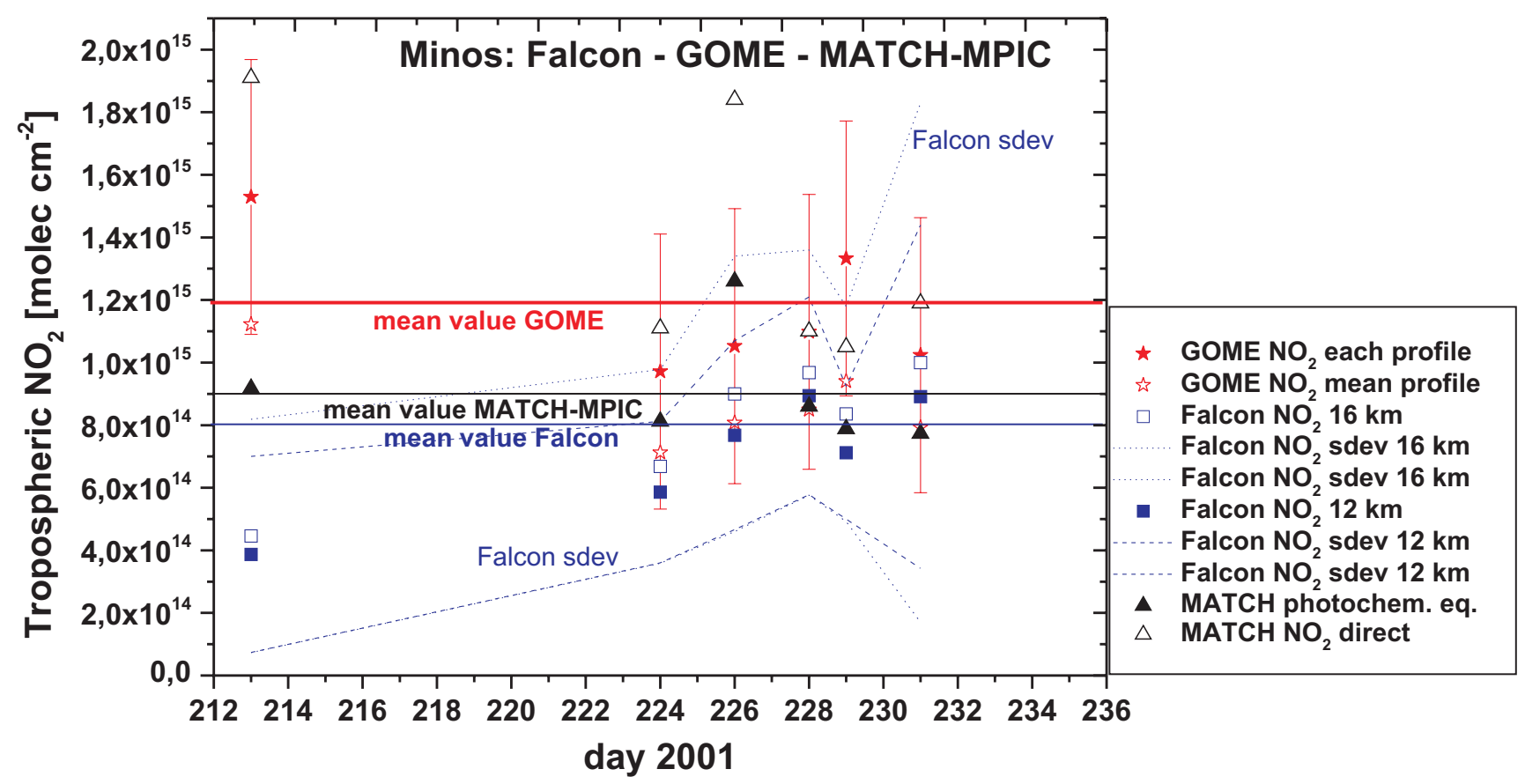

Fig. 6. Comparison of measurements of tropospheric vertical column densities of $\mathrm{NO}_{2}$ derived from in-situ-measurements and GOME data acquired during the MINOS campaign in July and August 2001. In addition MATCH-MPIC-model data determined using the same bin-averaging as for the in-situ measurements are also shown. See text for details.

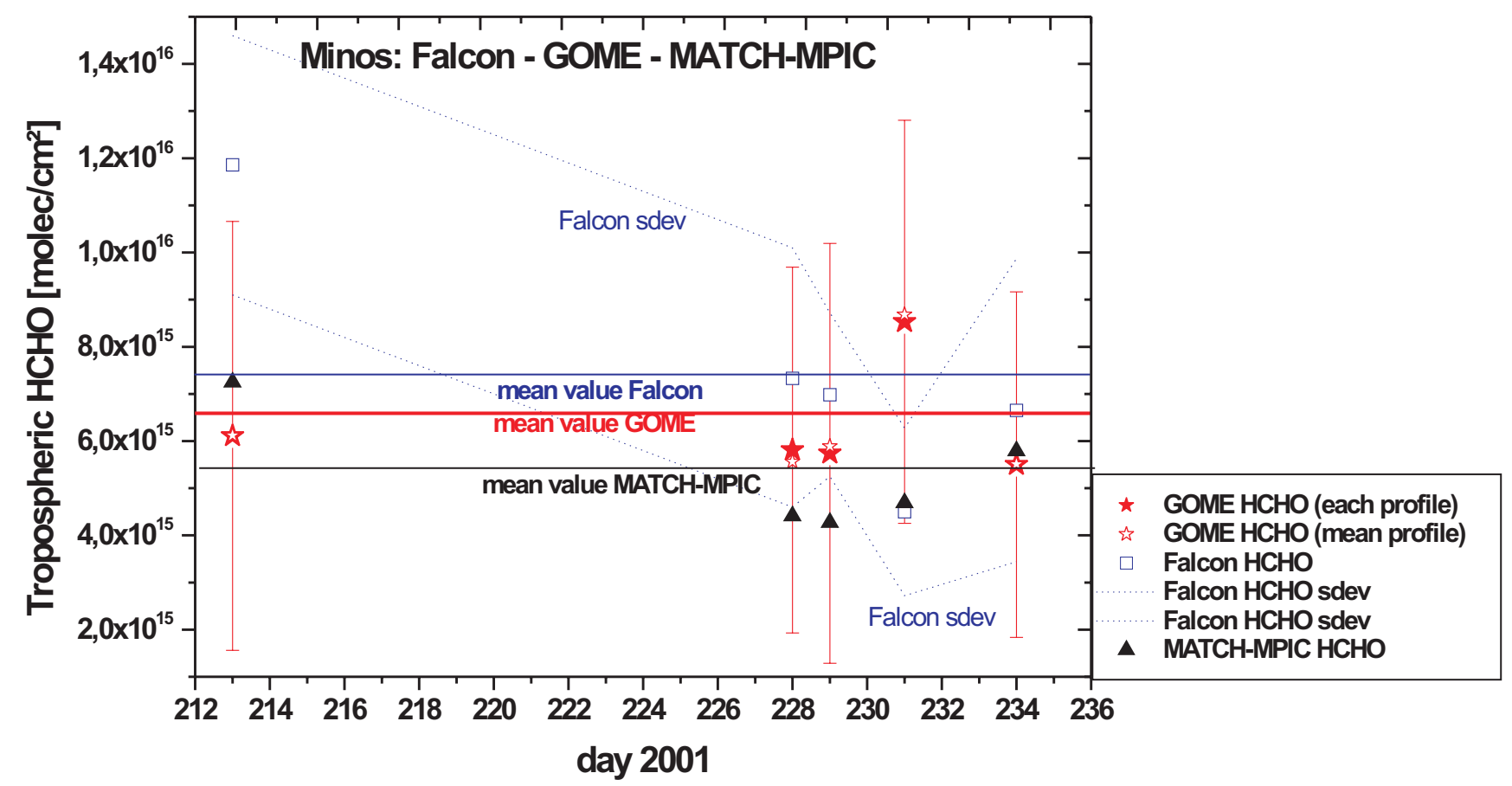

Fig. 7. Comparison of measurements of tropospheric vertical column densities of HCHO from in-situ-measurements (for HCHO $1 \mathrm{~km}$ bins) and GOME data acquired during the MINOS campaign in July and August 2001. In addition MATCH-MPIC-model data determined using the same bin-averaging as for the in-situ measurements are also shown. See text for details. 


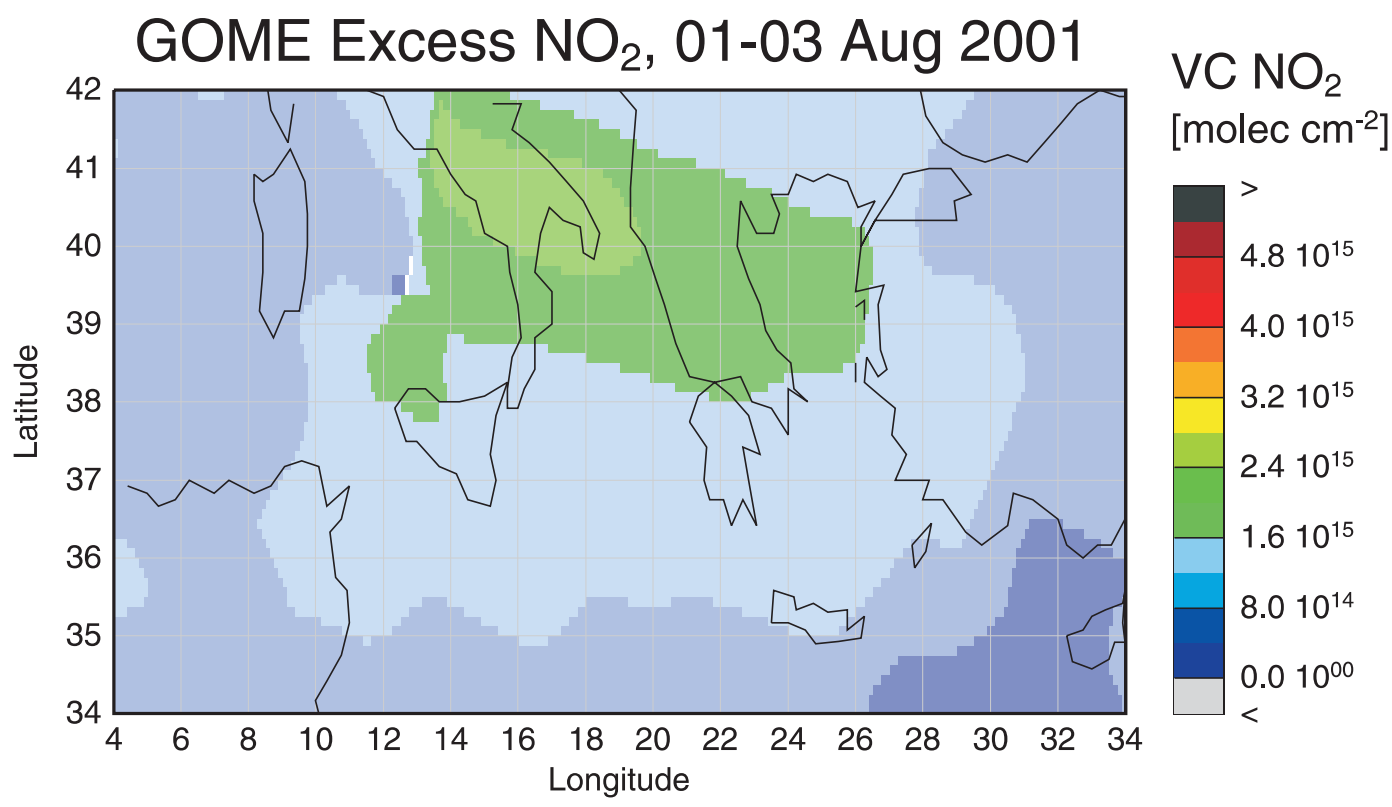

Fig. 8a. Averaged GOME measurements of tropospheric $\mathrm{NO}_{2}$ amounts in the time period of 1 to 3 August 2001 analysed for the Mediterranean region during the MINOS campaign.

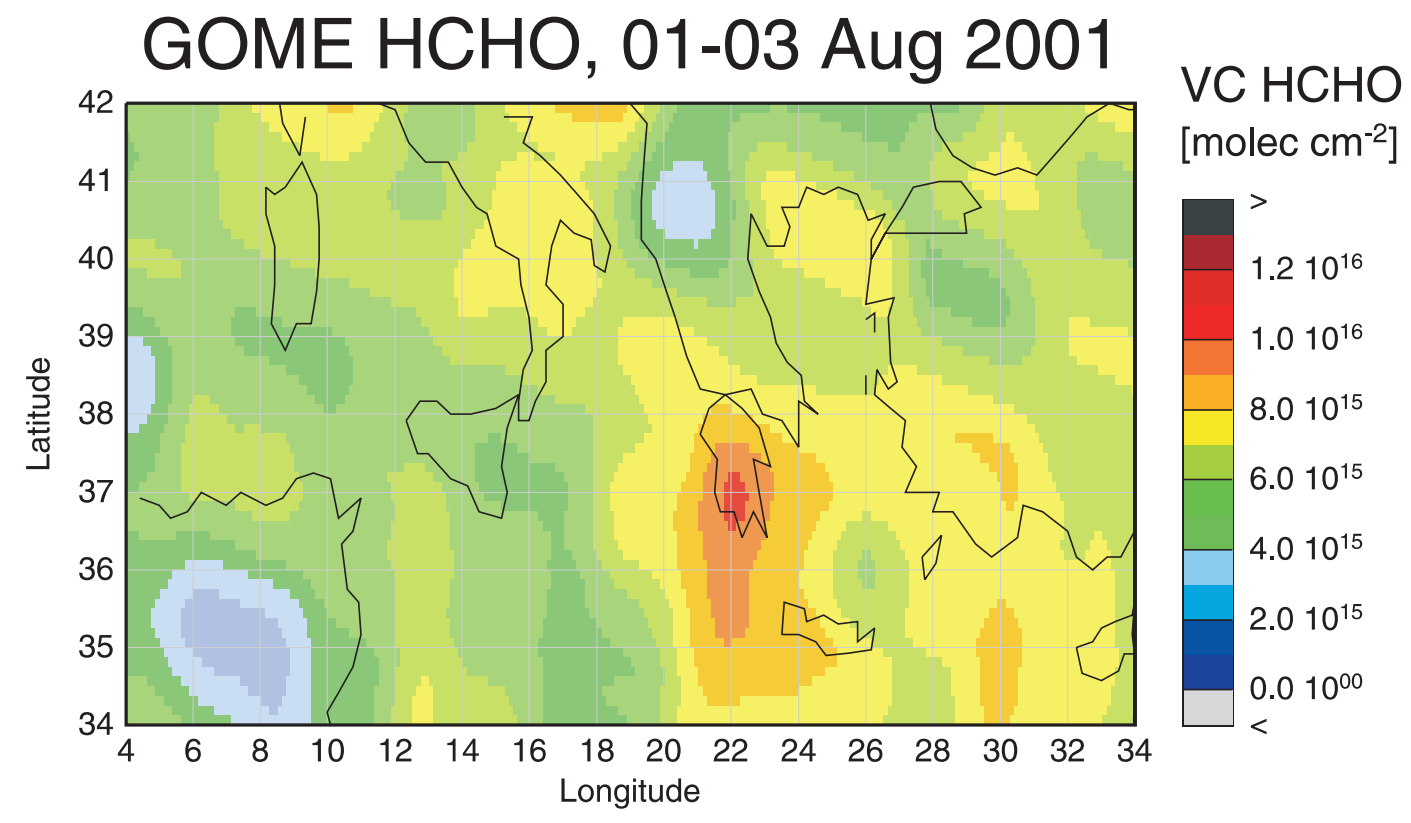

Fig. 8b. Averaged GOME measurements of tropospheric HCHO amounts in the time period of 1 to 3 August 2001 analysed for the Mediterranean region during the MINOS campaign.

output of the MATCH-MPIC-model and the in-situ measurements is $\sim 30 \%$, and the comparison between GOME and the results of the MATCH-MPIC-data shows a mean deviation of $\sim 17 \%$. In most cases the output of the MATCHMPIC-model shows lower values for the tropospheric vertical columns of HCHO compared to the measured data (Kormann et al., 2003). The reason for this discrepancy can be an underestimation of the emission of NMHCs (non methane hydro carbons) or the fact that reactions of terpenes are not explicitly included in the scheme, which implies that the precursors of $\mathrm{HCHO}$ in photochemical reactions are underestimated in the MATCH-MPIC-model. The emission of additional $\mathrm{CO}$ and acetone, which is used to compensate for the lack of terpene in the MATCH-MPIC-model in this case does 
Table 3. Calculation of the t-distribution with a degree of freedom of 10 for the trace gases $\mathrm{NO}_{2}$ and a degree of freedom of 8 for $\mathrm{HCHO}$

\begin{tabular}{lll}
\hline & $T$ (with $k=10$ for $\mathrm{NO}_{2}$ and $k=8$ for $\left.\mathrm{HCHO}\right)$ & Significance level \\
\hline $\begin{array}{l}\mathrm{NO}_{2} \\
\mathrm{GOME} \text { - in-situ }\end{array}$ & 3.23 & $>0.5 \%$ \\
$\mathrm{NO}_{2}$ & 4.05 & $>0.5 \%$ \\
$\begin{array}{l}\mathrm{GOME}-\mathrm{MATCH}-\mathrm{MPIC} \\
\mathrm{HCHO}\end{array}$ & 0.75 & $<0.1 \%$ \\
$\begin{array}{l}\text { GOME - in-situ } \\
\mathrm{HCHO}\end{array}$ & 0.65 & $<0.1 \%$ \\
GOME - MATCH-MPIC & 0.65 \\
\hline
\end{tabular}

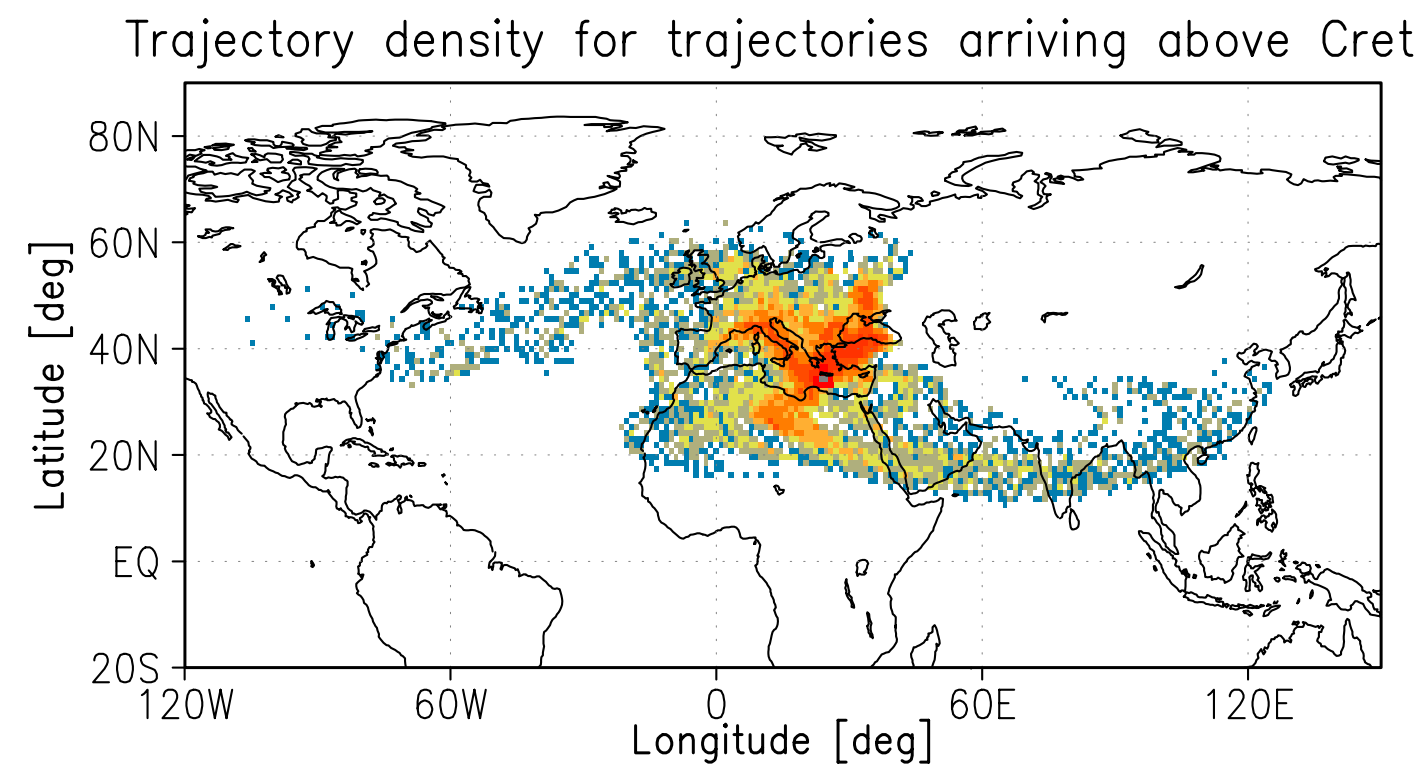

Fig. 9. Trajectory density for trajectories arriving at Crete between 1 and 3 August 2001. The trajectory density is derived by projecting all trajectories overpassing a certain location at any given height to the ground. Trajectories on all height levels are weighted equally. Therefore, this figure reveals no height information. The trajectory density is given in an arbitrary colour scale. As can be seen, air masses arriving at Crete overpass mainly southern central Europe, south eastern Europe and northern Africa.

not lead to HCHO columns as large as those observed. The same applies to some higher industrial hydrocarbons: e.g. aromatics and alkenes $>C_{3}$ (von Kuhlmann, private communication).

The HCHO profiles derived from in situ measurements show that typically about $60 \%$ of the total tropospheric vertical column, or $5.3 \times 10^{15} \mathrm{molec} / \mathrm{cm}^{2}$, are observed in the lower troposphere $(0-4 \mathrm{~km}) .28 .9 \%$ were detected in the lowest atmospheric layer $(0-1 \mathrm{~km}), 17.1 \%$ at a height of $1-$ $2 \mathrm{~km}, 11.5 \%$ between 2 and $3 \mathrm{~km}$ and $7.5 \%$ at $3-4 \mathrm{~km}$ altitude. The calculated mean GOME HCHO column $\left(6.4 \times 10^{15}\right.$ molec $/ \mathrm{cm}^{2}$ ) is about $20 \%$ lower than the averaged value of insitu data during the MINOS campaign. Still the agreement between both measurement systems is good and demonstrates the ability of GOME to measure HCHO under these conditions.
In order to compare the results of the two measuring systems (GOME and in-situ) more quantitatively, the tdistribution was used to asses the probability of measuring the observed values at the given standard deviation, considering that the physical quantity (tropospheric column of $\mathrm{NO}_{2}$ or $\mathrm{HCHO}$ ) is the same. Using the t-distribution, significance levels for the appropriate degrees of freedom can be determined (Sachs, 2000) (see Table 3). On the condition that both measurement systems (GOME - in-situ - measurements) are observing the same air masses, the significance level has a value of $>0.5 \%$ for the trace gas $\mathrm{NO}_{2}$, but $<0.1 \%$ for $\mathrm{HCHO}$. This implies that the results of the two measuring systems are consistent for $\mathrm{NO}_{2}$, but that they are less significant for $\mathrm{HCHO}$. 
Table 4. Classification of weather phenomena based on the Total Totals Index

\begin{tabular}{ll}
\hline Total Totals Index & Weather phenomenon \\
\hline $44-45$ & Isolated moderate thunderstorms \\
$46-47$ & Scattered moderate/few heavy thunderstorms \\
$48-49$ & Scattered moderate/few heavy/isolated severe thunderstorms \\
$50-51$ & Scattered heavy/few severe thunderstorms and isolated tornadoes \\
$52-55$ & Scattered to numerous heavy/few to scattered severe thunderstorms/few tornadoes \\
$>55$ & Numerous heavy/scattered severe thunderstorms and scattered tornadoes \\
\hline
\end{tabular}

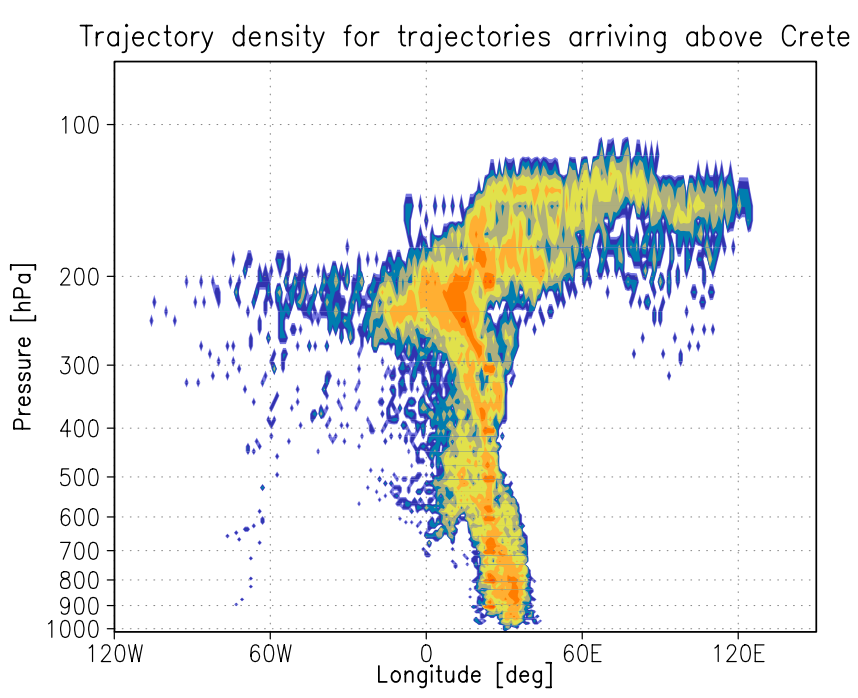

Fig. 10. Longitude-pressure projection of the trajectory density of all trajectories arriving over Crete from 1 to 3 August 2001. This projection reveals that trajectories originating above southeast-Asia are hardly influenced by anthropogenic pollution. For this graph an arbitrary colour scale is used.

4.2 Transport and build-up of tropospheric trace gases during the MINOS campaign

The measurements using the GOME instrument reveal enhanced tropospheric columns of $\mathrm{NO}_{2}$ and $\mathrm{HCHO}$ (see Figs. 8a and b) during the MINOS campaign in the Eastern Mediterranean region. For the episode from 1 to 3 August 2001 , this study shows an increase of the amount of $\mathrm{NO}_{2}$ to up to $2.6 \cdot 10^{15} \mathrm{molec} / \mathrm{cm}^{2}$ and of up to $1.1 \cdot 10^{16} \mathrm{molec} / \mathrm{cm}^{2}$ for the $\mathrm{HCHO}$ over this region.

From this we conclude that polluted air masses were present that were either transported towards this region or emitted locally. In order to answer this question, backtrajectories were calculated.

A very detailed analysis of the meteorology and the origin of airmasses arriving in the Mediteranian region is performed by (Lelieveld et al., 2002) and (Traub et al., 2003).
In contrast to the analysis performed by Traub our trajectory analysis was focussed explicitly on the 1st to 3rd of August when GOME measurements over the Eastern Mediteranian took place.

For our analysis backtrajectories are started over Crete at different heights (at 900, 800, 700, 600, 500, 400, 300, and $200 \mathrm{hPa}$ ) and travel backwards in time for 5 days. Every $6 \mathrm{~h}$ (at 00:00, 06:00, 12:00, and 18:00 UT) from 1 to $3 \mathrm{Au}-$ gust a new set of backtrajectories was released from the same starting point over Crete. One set contains trajectories being released at 900 to $200 \mathrm{hPa}$ on a $100 \mathrm{hPa}$ altitude grid. Altogether 800 trajectories were computed using Traj.x, a trajectory model developed at IUP-Bremen (Meyer-Arnek, 2002). For this study, the meteorological data from the ECMWF analysis model were used which are available on 60 height levels every $6 \mathrm{~h}$ (at 00:00, 06:00, 12:00, and 18:00 UT) and a spatial resolution of T511. Although the meteorological data have a high spatial and a very high vertical resolution within the planetary boundary layer, no trajectories arriving above Crete below $900 \mathrm{hPa}$ were considered. The reason is that turbulence on spatial and temporal scales smaller than the resolution of the meteorological data dominate the transport within the planetary boundary layer.

Figure 9 shows the trajectory density of all trajectories arriving over Crete. The trajectory density is derived by projecting all trajectories onto a latitude-longitude grid independent of their current height. Every occurrence of a trajectory within the boundaries of each gridpoint is counted. The figure shows that airmasses arriving at Crete overpass mainly southern central Europe, south eastern Europe and northern Africa. However, the trajectory density in this projection reveals no height information. Figure 11 shows where the trajectories on their way to Crete were at a given date (given in day of year; DoY). The day of year 208 refers to 27 July and DoY 213 refers to 1 August 2001.

In order to determine if anthropogenic pollution could have been transported to Crete, contacts of the trajectories with the planetary boundary layer were evaluated. It gives evidence that air masses being probed over Crete had ground contact mainly in the Black Sea region, and potentially could have brought pollution from this area. The longitudepressure-projection of the trajectory density suggests that air 

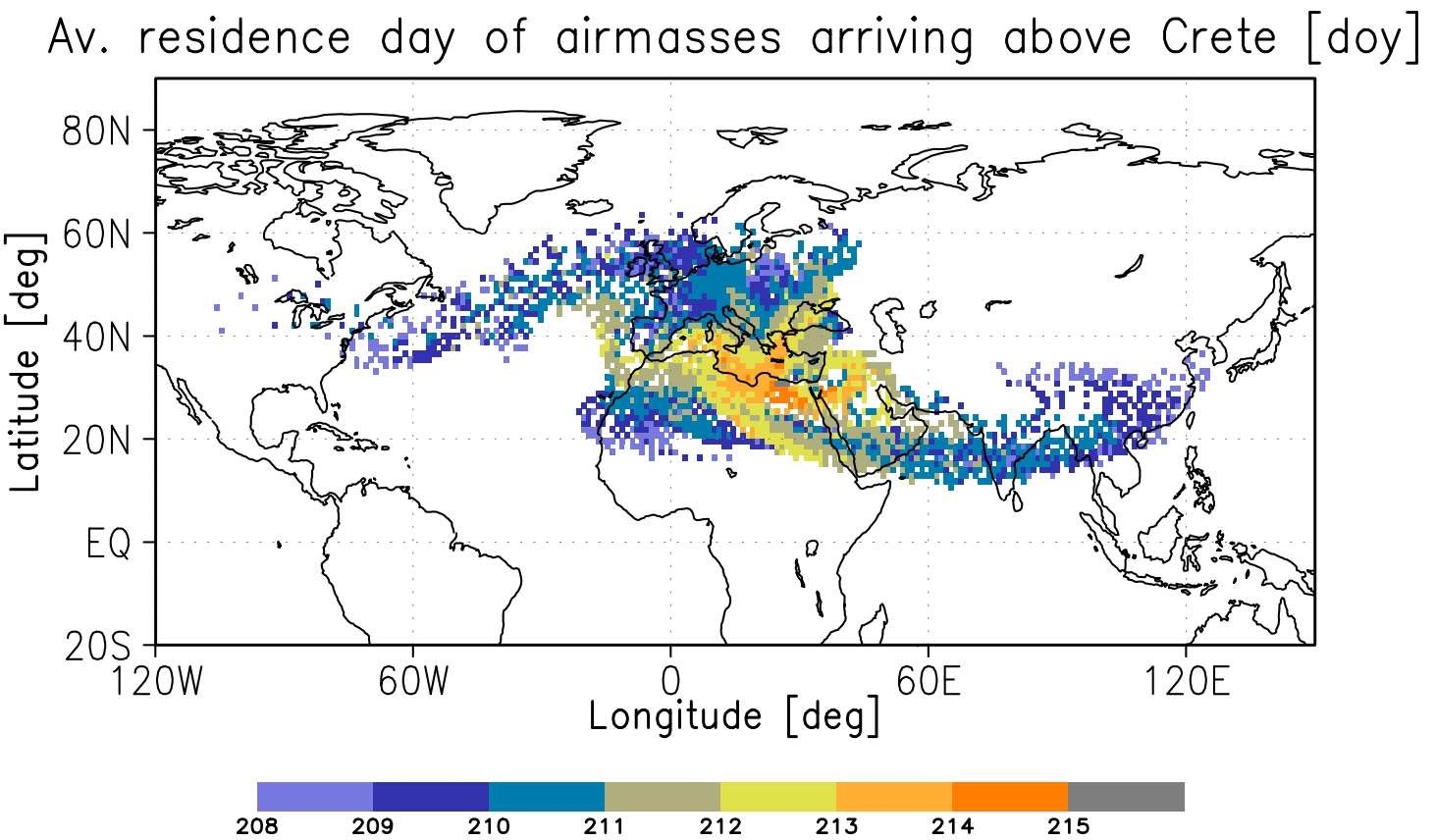

Fig. 11. Averaged date of the trajectories' occurrence at a distinct location (given as day of the year (DoY)). DoY 208 refers to 27 July 2001 , DoY 213 refers to 1 August 2001 and DoY 215 refers to 3 August 2001. Trajectories started around DoY 208 and 209 above south east Asia, northern Atlantic, north western Europe and western Africa in order to arrive above Crete from 1 to 3 August 2001. All times within each column are averaged to get one value per grid cell. Values close the arrival point should not be taken into account.

masses originating above south east Asia are not influenced by anthropogenic pollution (see Fig. 10). However, strong uplifting of air masses from the boundary layer into the free troposphere due to convection can not be excluded in such a trajectory calculation. Convection often takes place on horizontal scales of less than $10 \mathrm{~km}$ and on time scales of 10 to $20 \mathrm{~min}$. This means that convection has to be regarded as a parameterized subgrid process by a global model (like the ECMWF analysis model) (Tiedke, 1989). In order to find out whether air masses have been uplifted from the boundary layer into the major trajectory paths by convection, the Total Totals Index (see Table 4) was calculated for every $6 \mathrm{~h}$ in the period from 27 July to 3 August. The Total Totals Index is a simple index derived from the temperature lapse rate between 850 and $500 \mathrm{hPa}$ and from the moisture content at $850 \mathrm{hPa}\left(T_{\text {dew }}(850)\right)$.

$$
T T I=T_{\text {dew }}(850)-T(500)+(T(850)-T(500))
$$

The likelihood of thunderstorms increases with an increasing Total Totals Index. The risk of severe weather due to atmospheric instability in the US is empirically defined as follows: As a rule a thumb a Total Totals Index of more than 44 implies convection. Since the index stayed below 44 over south east Asia around 27 July 2001 it indicates that no strong convection was taking place above this area (see Fig. 12).
In summary, the enhanced trajectory analysis reveals no indication for Asian plumes reaching Crete during 1 to $3 \mathrm{Au}-$ gust 2001. On the other hand it is likely that boundary layer air was uplifted during the overpass of the trajectories above Europe since the Total Totals Index shows convection above Great Britain and Central Europe on 27 July and the Black Sea Region on 31 July 2001 (see Fig. 12).

\section{Summary}

In this study, GOME satellite measurements of $\mathrm{NO}_{2}$ and $\mathrm{HCHO}$ are compared with in-situ measurements and model results for a number of days during the MINOS campaign in August 2001. Good agreement was found between the GOME and in-situ measurements for both absorbers, demonstrating the ability of GOME measurements to derive accurate $\mathrm{NO}_{2}$ and $\mathrm{HCHO}$ columns under these conditions when columns were close to the detection limit of GOME. This constitutes the first however limited validation of a GOME $\mathrm{HCHO}$ product.

The impact of the vertical distribution of the trace species on the GOME data retrieval has been analysed using weighting functions or block airmass factors. Although the sensitivity of the satellite instruments towards absorptions in the $\mathrm{BL}$ is smaller than for absorptions in the free troposphere, in particular for $\mathrm{HCHO}$, using appropriate vertical profiles in 

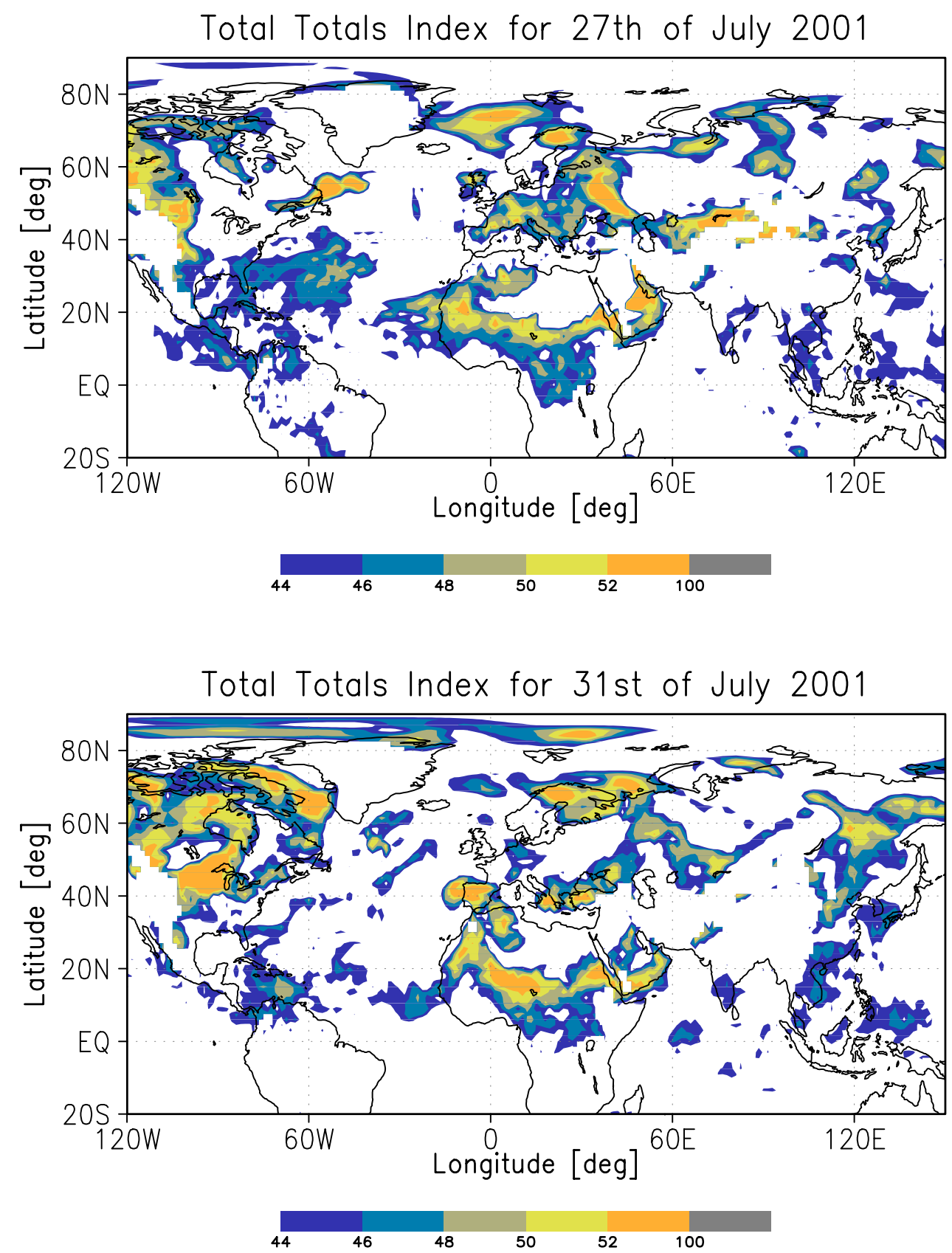

Fig. 12. Total Totals Index for 27th and 31st of July 2001. On 27th of July some thunderstorm activity above Europe but hardly any activity above south east Asia is recognizable. On 31st of July thunderstorm activity above the Black Sea region and in the north eastern region of the Mediterranean Sea takes place. This may cause uplifting of anthropogenically polluted air from the boundary layer into the free troposphere.

the airmass factor calculation can account for this effect. The impact of variations in vertical profile as observed during the campaign by the in-situ measurements was also studied and found to be non-negligible for $\mathrm{NO}_{2}$ (up to $30 \%$ ) but small for HCHO.
Data from the MATCH-MPIC model were also compared to in-situ and GOME measurements, and showed good agreement with the measurements. For $\mathrm{NO}_{2}$, two different methods were used, one relying on simple photostationary state assumptions and the other on deriving the difference 
between $\mathrm{NO}_{\mathrm{x}}$ and $\mathrm{NO}$. The latter method yielded much better agreement between model and measurements, highlighting the importance of other $\left(\mathrm{RO}_{\mathrm{x}}\right)$ reactions in $\mathrm{NO}_{2}$ formation. For $\mathrm{HCHO}$, the model consistently underestimated the tropospheric columns, probably as a result of neglecting terpene chemistry.

The results of both measurement systems were found to agree within their accuracy limits even though the tropospheric vertical columns of these trace gases were often near the detection limit of GOME.

A case study of transport processes in combination with analyses of back-trajectories show that most of the polluted air masses came from the European continent during the time period of 1 to 3 August 2001. Air masses from SE Asia were probably not influenced by pollution at that time, but some uplifting of airmasses from the BL took place in Europe.

Acknowledgements. Parts of this work were funded by the University of Bremen, Germany, the DLR/DARA, the European Community, and the European Space Agency (ESA). We especially thank the organizers of the MINOS campaign J. Lelieveld, MaxPlanck-Institute for Chemistry, Atmospheric Chemistry Department, Mainz, Germany and N. Mihalopoulos, Crete University, Environmental Chemical Processes Laboratory, Department of Chemistry, Greece and the helpful assistance of M. de Reus. Meteorological analysis data were kindly provided by the European Centre for Medium Range Weather Forecast (ECMWF); GOME radiances and irradiances were provided by ESA through DLR/DFD in Oberpfaffenhofen.

\section{References}

Atkinson, R.: Atmospheric chemistry of VOCs and $\mathrm{NO}_{\mathrm{x}}$, Atmos. Environ., 34, 2063-2101, 2000.

Burrows, J. P., Weber, M., Buchwitz, M., Rozanov, V. V., Ladstätter-Weissenmayer, A., Richter, A., de Beek, R., Hoogen, R., Bramstedt, K., Eichmann, K.-U., Eisinger, M., und Perner, D.: The Global Ozone Monitoring Experiment (GOME): Mission Concept and First Scientific Results, J. Atm. Sciences, 56, 151-175, 1999.

Burrows, J. P., Richter, A., Weber, M., Eichmann, K.-U., Bramstedt, K., Ladstätter-Weißenmayer, A., Wittrock, F., Eisinger, M., and Hild, L.: Satellite observations of tropospheric and stratospheric gases, in: Chemistry and Radiation Changes in the Ozone Layer, edited by Zerefos, C., 301-329, Kluwer Academic Publisher, 2000

Calvert, J. G. and Stockwell, W. R.: Deviations from the $\mathrm{O}_{3}$ $\mathrm{NO}-\mathrm{NO}_{2}$ photostationary state in tropospheric chemistry, Can. J. Chem., 61, 983-992, 1983.

Chance, K., Palmer, P., Spurr, R. J. D., Martin, R. V., Kurosu, T. P., and Jacob, D. J.: Satellite observations of formaldehyde over North America from GOME, Geophys. Res. Lett., 27, 34613464, 2000.

Crawford, J., Davis, D., Chen, G., Bradshaw, J., Sandholm, S., Gregory, G., Sachse, G., Anderson, B., Collins, J., Blake, D., Singh, H., Heikes, B., Talbot, R., and Rodriguez, J.: Photostationary state analysis of the $\mathrm{NO}_{2}$-NO system based on airborne obser- vations from the western and central North Pacific, J. Geophys. Res., 101, 2053-2072, 1996.

Eskes, H. J. and Boersma, K. F.: Averaging kernels for DOAS totalcolumn satellite retrievals, Atmos. Chem. Phys., 3, 1285-1291, 2003

Fishman, J., Watson, C. E., Larsen, J. C., and Logan, J. A.: The distribution of tropospheric ozone determined from satellite data, J. Geophys. Res., 95, 3599-3617, 1990.

Hauser, C.: Charakterisierung eines Messsystems zur Bestimmung der $\mathrm{NO}_{2}$-Photolysefrequenz in der Troposphäre - Labormessungen und Flugzeugmessungen, Diplomarbeit, Fachhochschule München, DLR, Oberpfaffenhofen, 2002.

Heland, J., Schlager, H., Richter, A., and Burrows, J.: First comparison of tropospheric $\mathrm{NO}_{2}$ column densities retrieved from GOME measurements and in situ aircraft profile measurements, Geophys. Res. Lett., 29, 2, 44-1-44-4, 2002.

Junkermann, W., Platt, U., and Volz-Thomas, A.: A Photoelectric Detector for the Measurement of Photolysis Frequencies of Ozone and Other Atmospheric Molecules, J. Atmos. Chem., 8, 203-227, 1989.

Kelly, T. J. and Fortune, C. R.: Continuous monitoring of gaseous formaldehyde using an improved fluorescence approach, Int. J. Env. Anal. Chem., 54, 249-263, 1994.

Kormann, R., Fischer, H., de Reus, M., Lawrence, M. G., Brühl, Ch., von Kuhlmann, R., Holzinger, R., Williams, J., Lelieveld, J., Warneke, C., de Gouw, J., Heland, J., Ziereis, H., and Schlager, H.: Formaldehyde over the Eastern Mediterranean during MINOS: Comparison of Airborne In-situ Measurements With 3-DModel Results, Atmos. Chem. Phys., 3, 851-861, 2003

Ladstätter-Weissenmayer, A., Burrows, J. P., and Perner, D.: Biomass burning over Indonesia as observed by GOME, Earth Obs. Quart. 58, 28-29, 1998.

Lawrence, M. G. , Crutzen, P. J., Rasch, P. J., Eaton, B. E., and Mahowald, N. M.: A model for studies of tropospheric photochemistry: Description, global distributions and evaluation, J. Geophys. Res., 104, 26 245-26 277, 1999.

Lawrence, M. G., Rasch, P. J., von Kuhlmann, R., Williams, J., Fischer, H., de Reus, M., Lelieveld, J., Crutzen, P. J., Schultz, M., Stier, P., Huntrieser, H., Heland, J., Stohl, A., Forster, C., Ebern, H., Jakobs, H., and Dickerson, R. R.: Global chemical weather forcasts for field campaign planning: predictions and observations of larger-scale features during MINOS, CONTRACE, and INDOEX, Atmos. Chem. Phys., 3, 267-289, 2003.

Lelieveld, J., Berresheim, H. Bormann, S. Crutzen, P. J., Dentener, F. J., Fischer, H., Feichter, J., Flateu, P. J., Heland, J., Holzinger, R., Korrmann, R., Lawrence, M. G., Levin, Z., Markowitz, K. M., Mihalopoulos, N., Minikin, A., Ramanathan, V., de Reus, M., Roelofs, G. J., Scheeren, H. A., Sclare, J., Schlager, H., Schultz, M., Siegmund, P., Steil, B., Stephanou, E. G., Stier, P., Traub, M., Warneke, C., Willians, J., and Ziereis, H.: Global air pollution crossroads over the Mediterranean, Science, 298, 794799, 2002

Leue, C., Wenig, M., Wagner, T., Platt, U., and Jähne, B.: Quantitative analysis of $\mathrm{NO}_{\mathrm{x}}$ emissions from GOME satellite image sequences, J. Geophys. Res., 106, 5493-5505, 2001.

Levine, J. S.: Global biomass burning: Atmospheric, climatic and biospheric implications, Global biomass burning, Atmospheric, climatic, and biospheric implications, edited by Levine, 1991.

Macdonald, A. M., Wiebe, H. A., Li, S. M., Dryfhout-Clark, H., 
Asalian, K., Lu, G., Wang, D., Schiller, C. L., Harris, G. W., Sumner, A. L., and Shepson, P. B.: Results of a formaldehyde intercomparison study in Ontario, Atmospheric Environment Service, Ontario, Canada, 1999.

Martin, R. V., Chance, K., Jacob, D. J., Kurosu, T. P., Spurr, R. J. D., Bucsela, E., Gleason, J. F., Palmer, P. I., Bey, I., Fiore, A. M., Li, Q., Yantosca, R. M., and Koelemeijer, R. B. A.: An improved retrieval of tropospheric nitrogen dioxide from GOME, J. Geophys. Res., 107(D20), 4437, 10.1029/2001JD001027, 2002.

Meyer-Arnek, J., Numerical validation, manual and userguide for Traj.x, iup-Bremen, 2002.

Nash, T.: The colorimetric estimation of formaldehyde by means of the Hantzsch reaction, Biochemistry, 55, 416-421, 1953.

Olivier, J. G. J., Bouwman, A. F., van der Maas, C. W. M., Berdowski, J. J. M., Veldt, C., Bloos, J. P. J., Visschededijk, A. J. J., Zandveld, P. Y. J., and Haverlag, J. L.: Description of EDGAR Version 2.0: A set of global inventories of greenhouse gases and ozone-depleting substances for all anthropogenic and most natural sources on a per country $1^{\circ} \times 1^{\circ}$ grid. RIVM Rep, 771060002, Rijksinstituut, Bilthoven, The Netherlands, 1996.

Palmer, P. I., Jacob, D. J., Fiore, A. M., Martin, R. V., Chance, K., and Kurosu, T. P.: Mapping isoprene emissions over North America using formaldehyde columns observations from space, J. Geophys. Res., 101, 2053-2072, 2002.

Richter, A. and Burrows, J. P.: Retrieval of tropospheric $\mathrm{NO}_{2}$ from GOME measurements, Adv. Space Res., 29, 11, 1673-1683, 2002.

Rozanov, V., Diebel, D., Spurr, R. J., and Burrows, J. P.: GOMETRAN: A radiative transfer model for the satellite project GOME - the plane parallel version, J. Geophys. Res., 102, 1668316 695, 1997.

Sachs, L.: Angewandte Statistik, Springer-Verlag, 2000.

Sander, S. P., Friedl, R. R., DeMore, W. B., Golden, D. M., Kolb, C. E., Kurylo, M. J., Hampson, R. F., Huie, R. E., Molina, M. J., and Moortgat, G. K.: Chemical Kinetics and Photochemical Data for Use in Stratospheric Modeling, Supplement to Evaluation 12: Update of Key Reactions, JPL Publication 00-3, NASA Panel for Data Evaluation, Evaluation Number 13, 8 March 2000, Jet Propulsion Laboratory, Pasadena, California, 2000.
Shimizu, A. and Tsuda, T.: Variations in tropical tropopause observed with radiosondes in Indonesia, Geophys. Res. Lett, 27, 16, 2541-2544, 2000.

Tiedke, M.: A Comprehensive Mass Flux Scheme for Cumulus Parameterization in Large Scale Models, Monthly Weather Review, August 1989.

Traub, M., Fischer, H., de Reus, M., Korrmann, R., Heland, J., Ziereis, H., Schlager, H., Holzinger, R., Williams, J., Warneke, C., de Grouw, J., and Lelieveld, J.: Chemical characteristics assigned to trajectory clusters during the MINOS campaign, J., Atmos. Chem. Phys., 3, 459-468, 2003

Volz-Thomas, A., Lerner, A., Pätz, H. W., Schulz, M., McKenna, D. S., Schmitt, R., Madronich, S., and Röth, E. P.: Airborne measurements of the photolysis frequency of $\mathrm{NO}_{2}$, J. Geophys. Res., 101, 18 613-18 627, 1996.

von Kuhlmann, R.: Tropospheric photochemistry of $\mathrm{O}_{3}$, its precursors and the hydroxyl radical: A 3D modeling study considering Non-Methane hydrocarbons, PhD Thesis, University of Mainz, Germany, 2001.

von Kuhlmann, R., Lawrence, M. G., Crutzen, P. J., and Rasch, P. J.: A Model for Studies of Tropospheric Ozone and Non-Methane Hydrocarbons: Model Description and Ozone Results, J. Geophys. Res., 108, D9, DOI10.1029/2002JD002893, 2003.

Wagner, V., v. Glasow, R., Fischer, H., and Crutzen, P. J.: Are $\mathrm{CH}_{2} \mathrm{O}$ measurements in the Marine boundary layer suitable for testing the current understanding of $\mathrm{CH}_{4}$ photooxidation?, A model study, J. Geophys. Res., 107, 10 1029-10 1043, 2002.

Ziereis, H, Schlager, H., Schulte, P., Köhler, I., Marquardt, R., and Feigl, C.: In situ measurements of the $\mathrm{NO}_{\mathrm{X}}$ distribution and variability over the eastern North Atlantic, J. Geophys. Res., 104, 16021-16 032, 1999. 